\title{
A STUDY TO DETECT THE SAFETY OF ELECTRONIC CIGARETTE ON THE TASTE BUDS OF ALBINO RATS TONGUE PAPILLAE
}

\author{
Mohamed Abdelrahman* and Mahmoud Elsherbeny**
}

\begin{abstract}
Background: Electronic cigarette is a substitute to traditional nicotine smoke invented since 2004. There is no enough data about its safety with its the widespread usage.

Aim of the study: The present study was designed to verify the impact of E-liquid of electronic cigarette on taste buds of fungiform papillae in albino rats.

Materials and methods: 22 young adult male albino rats were divided into 3 groups. Group I: (control group), injected i.p by normal saline daily. Group II: (E-cigarette group): animals were injected i.p by E-cigarette refill liquid (ECRL) containing $0.5 \mathrm{mg}$ of nicotine $/ \mathrm{kg}$ for 6 days then continue to be administered the same dose day after day for 4 weeks. Group III (E-cigarette + vitamin $\mathrm{C}$ treated group): animals had been i.p injected by (ECRL) containing $0.5 \mathrm{mg}$ of nicotine/ $\mathrm{kg}$. One hour from i.p injection of the liquid, the animals were received vitamin C $300 \mathrm{mg} / \mathrm{kg}$ through oro-gastric gavage for 6 days. Then animals were receive the regimen day after day till the end of 4 weeks. Rats of groups sacrificed 24 hs from last injection. After processing the tissue samples, they were stained using Haematoxylin \& Eosin and Cytokeratin $7 \&$ TNF $\alpha$. The results were analyzed statistically using one way ANOVA test.
\end{abstract}

Results: Evaluation of the sections revealed significant differences between all groups with marked improvement in group III. p value was less than 0.05 .

Conclusion: E-cigarette smoking has a harmful effect on taste buds of fungiform papilla histologically and immunohistochemically. Vitamin $\mathrm{C}$ has a protective effect on taste bud against E-cigarette refill liquid.

\section{INTRODUCTION}

To overcome smoking, many alternatives exist, one of them is the electronic cigarette (E-cig). It was invented and patented by Hon Lik, a Chinese pharmacist, and appeared in the market in 2004, as a substitution to smoking, ${ }^{(1)}$. These alternative products (electronic cigarette refill liquids) created a form of enthusiasm, being viewed as a healthy method in the managing and control of cessation of smoking ${ }^{(2)}$. They (ECs) are aerosol-producing

*Associate Professor of Oral Biology, Faculty of Dentistry, Mansoura University

**Lecturer of Oral Pathology, Faculty of Dentistry, Mansoura University 
devices designed to resemble the conventional tobacco cigarettes use. Though electronic cigarettes are considered less addictive and more safe than tobacco cigarettes, the marked abuse and other health consequences result from their usage had not been well studied, ${ }^{(3,5)}$. However, E-Cig becoming popular, particularly between smokers and young adolescents, ${ }^{(4,6)}$.

ECs do not burn tobacco; but they produce an aerosol (without smoke or flame) through a battery powered metal heating element and liquidcontaining cartridge, ${ }^{(7)}$. Propylene glycol (PG) $70 \%$, vegetable glycerin (VG) 30\%, nicotine, distilled water and flavors (including tobacco, sweet flavors, menthol and combinations) are the main constituents of ECs liquid, ${ }^{(8,9,10,11)}$.

Taste is the important sensory modality that guides organisms for identification and consuming food materials and avoiding toxins and other nondigested substances. Individual variation in the degree of tolerance of taste may have significant role in nutrition and selection of food which has an effect on our health and life quality, ${ }^{(12,13)}$. The gustatory system is solitary and exclusive in that taste bud innervations is decisive to the turnover of cellular components of taste bud, ${ }^{(14)}$.

Vitamin $\mathrm{C}$ is an effective free radical scavenger and it is the strongest determinants of total antioxidant capability of plasma, ${ }^{(15)}$. Most of the protective antioxidant effect of ascorbate is due to its action as an electron donor that undergoes $\mathrm{pH}$-dependent oxidation producing hydrogen peroxide, ${ }^{(16)}$. As E-cig became widespread and could be considered a nicotine substitute, there is no sufficient evidence supporting their safety. Considering the information scarcity related to the toxicity of e-cigarette, the present study was designed to verify the impact of E-liquid of electronic cigarette on taste buds of fungiform papillae in albino rats using cytokeratin $7 \&$ Tumor necrosis $\alpha$ antibodies.

\section{MATERIALS AND METHODS}

\section{Animals' preparation and experimental approach}

A total of 22 young adult male Sprague dawley albino rats weighing 180-200 gm were used. For acclimatization, rats were kept for 3 days before the onset of experiment and housed in metal cages at room temperature $25^{\circ} \mathrm{C}, 12$ hours light dark cycle in the research laboratory of the Nile Center for Experimental Research, Mansoura, Egypt. Water and food were allowed to rats ad libitum. The experiments were carried out according to the protocol approved by the local committee of ethics, Faculty of Dentistry, University of Mansoura.

\section{Drugs and chemicals:}

Electronic cigarette refill bottles $30 \mathrm{ml}(6 \mathrm{mg} /$ $\mathrm{ml}$ of nicotine) caramel tobacco flavor was obtained from commercial shops. Vitamin C bottles $15 \mathrm{ml}$ $(100 \mathrm{mg} / \mathrm{ml})$, oral drops, orange flavored, dietary supplement; El hadidy Pharm Company, obtained from pharmacy.

Animals grouping: Animals were divided as the following:

Group I (6 animals): served as a control group. Through i.p. injection, they received normal saline daily for 4 weeks.

Group II: (E-cigarette group, 8 rats): Animals were injected intra-peritoneally by E-cigarette refill liquid (ECRL) containing $0.5 \mathrm{mg}$ of nicotine $/ \mathrm{kg}$, (17) for 6 days then continue to be administered the same dose day after day for 4 weeks.

Group III (E-cigarette + vitamin C treated group, 8 rats): At the beginning, animals had been intraperitoneally injected by (ECRL) containing $0.5 \mathrm{mg}$ of nicotine $/ \mathrm{kg}$, and after one hour from i.p injection of the liquid, the animals were received vitamin C $300 \mathrm{mg} / \mathrm{kg}{ }^{(18)}$ through oro-gastric gavage. This process continued for 6 days. Then animals were received the regimen day after day till the end of 
4 weeks. Rats of each group had been weighted every week for adjusting the dose.

Rats were anaesthetized with ether, scarified by decapitation 24 hours from the last injections. Tongues were excised from animals at the time of sacrifice, cleared off blood and immediately fixed in $10 \%$ formalin and embedded in paraffin. Sections of $4 \mu \mathrm{m}$ thickness were cut and stained with:

\section{* Haematoxylin \& Eosin}

\section{* Cytokeratin 7 \& TNF- $\alpha$ immunostains}

\section{Immunohistochemical staining:}

After fixation the tissues, sections were stained immunohistochemically using monoclonal antibodies against cytokeratin-7 and TNFa. The procedure proceeded according to the manufacturing instructions.

\section{Immunostain evaluation:}

The slides were photographed by Olympus ${ }^{\circledR}$ digital camera installed on Olympus ${ }^{\circledR}$ microscope with $1 / 2 \mathrm{X}$ photo adaptor, using $\mathrm{X}$ objective. Analyzing the resulted images occurred on Intel ${ }^{\circledR}$ Core I3 ${ }^{\circledR}$ based computer through Video software (Test Morphology ${ }^{\circledR}$ ) (Russia, Saint-Petersburg) with a specific built-in automated object counting and stain quantification routines. 5 slides from each group were prepared, 5 random fields from each slides were analyzed. For cytokeratin 7, the cellular reactions were assessed and scored as the cells were positive. The data were tabulated, coded and then analyzed using SPSS version 17, One Way ANOVA test .

As for TNF $\alpha$, the severity of reactions in all sections were assessed subjectively by 3 separate observers (not involved in the work) using the following gradation: $<10 \%$ of cells stained, considered grade weak. $>10$ but $<25 \%$ of cells stained, grade mild. $>25$ but $<50 \%$ of cells stained, grade moderate. $>50$ but $<100 \%$ of cells stained, grade severe.

\section{Digital Surface Image Analysis}

Immuno-reactivity of cytokeratin-7 and TNF $\alpha$ and measuring the relation between surface area of bud and papilla (bud/papilla ratio, fig 1,A) were assessed by the image analysis software (Image $\mathrm{J}$, $1.29 \mathrm{t}, \mathrm{NIH}, \mathrm{USA})$. Images were acquired by a high resolution single chip CCD video camera in regions with subjectively the highest number of immunoreactivity cells. A total of 4 adjacent medium power microscopic fields were analyzed at the power of $20 \mathrm{x}^{(19)}$. To achieve maximum standardization, automatic guided color thresholding was adopted. The total surface area of immune-reaction was calculated by computer and expressed as a fraction of the total surface area of the microscopic field, ${ }^{(20)}$.

\section{RESULTS}

\section{Histological results}

Group I: The taste buds showed ovoid or barrelshaped appearance extends from the basement membrane to the surface of epithelium with apparent taste pore. Taste bud is completely enclosed within the stratified papillary epithelium with regular arrangement of outer supporting and inner short cells. The bud/ papilla ratio is 0.188 , fig 1 (A).

Group II: showed round shaped taste bud with haphazard arrangement of its component cells and vaculation. The bud/ papilla ratio is 0.097, fig 2 (B).

Group III: showed round taste bud with visible taste pore and apparent redistribution of its component cells. The bud/ papilla ratio 0.107 , fig 1 (C).

\section{Immunohistochemical results:}

\section{Cytokeratin 7}

Group I: shows moderate reaction of taste bud cells concentrated in the middle area.

Group II: shows weak reaction

Group III: shows mild reaction and occupying mostly the lower area of taste bud. 
TNF $\alpha$

Group I: shows weak reaction at the periphery of the bud.
Group II: shows weak reaction scattered through the periphery and basal area of the bud.

Group III: shows weak reaction at the periphery and middle area of the bud.

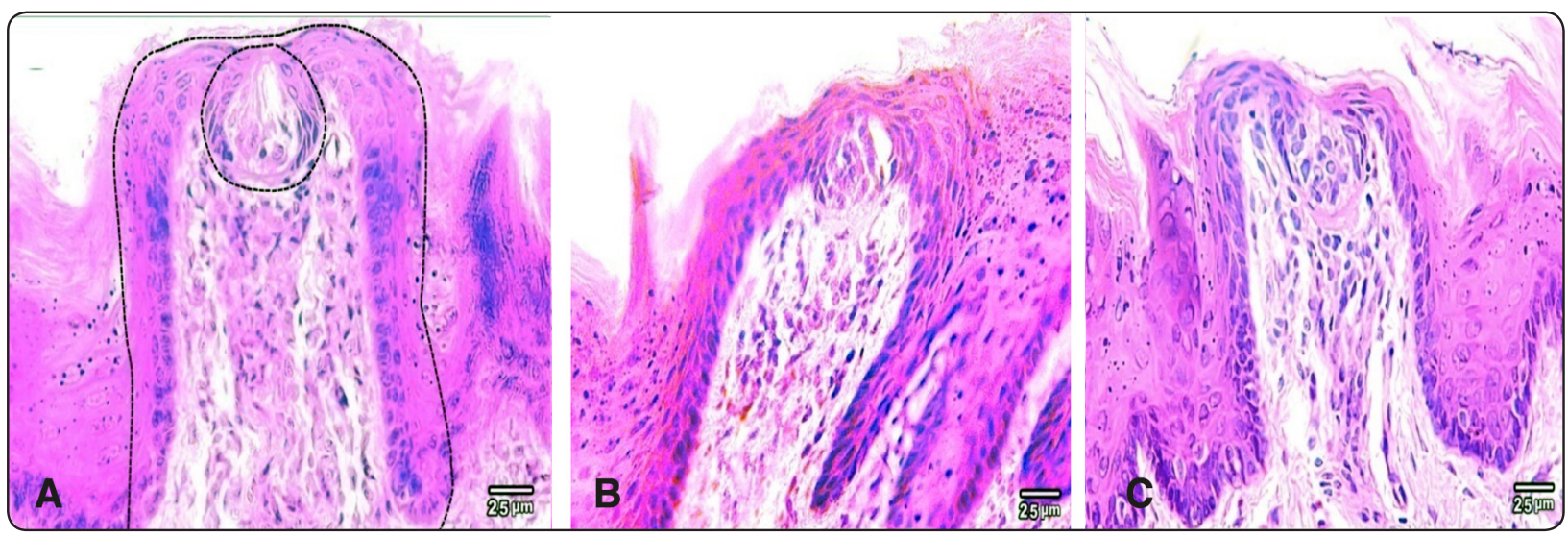

Fig. (1): Histological sections A, B and C. Note the outlining of taste bud and papilla boundary (in A) to measure bud/papilla ratio. (X. 400)

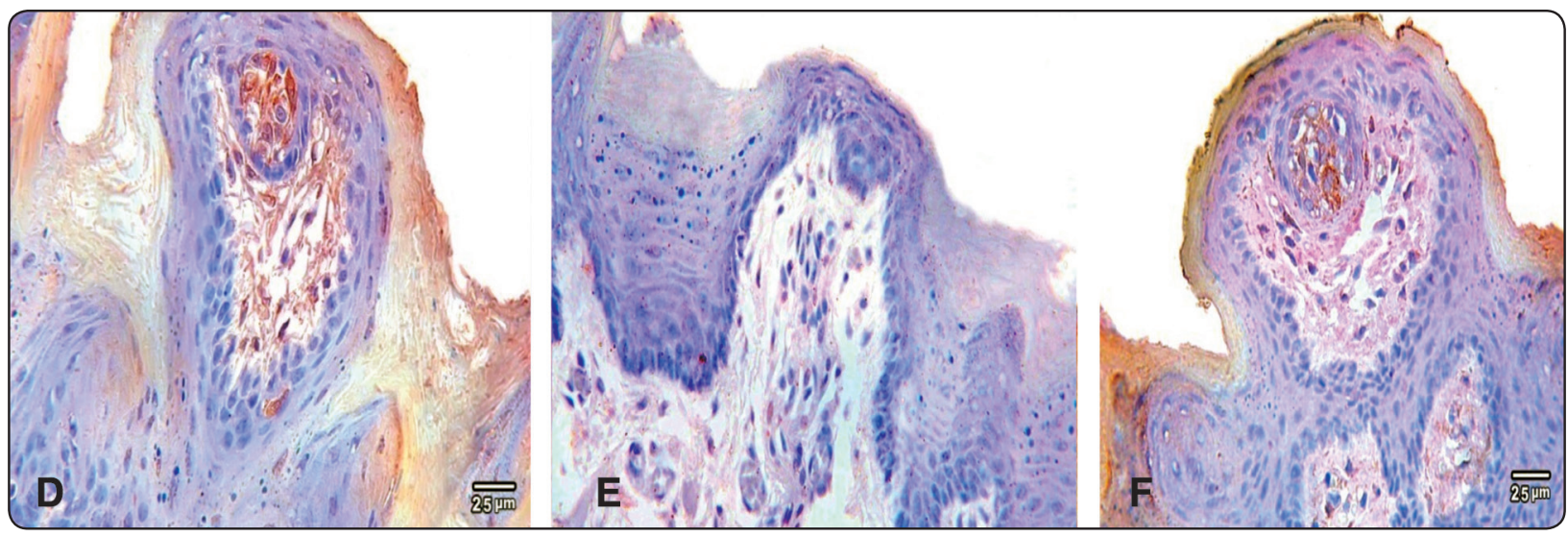

Fig. (2) Cytokeratin 7 immunostain sections D, E and F. (X. 400).

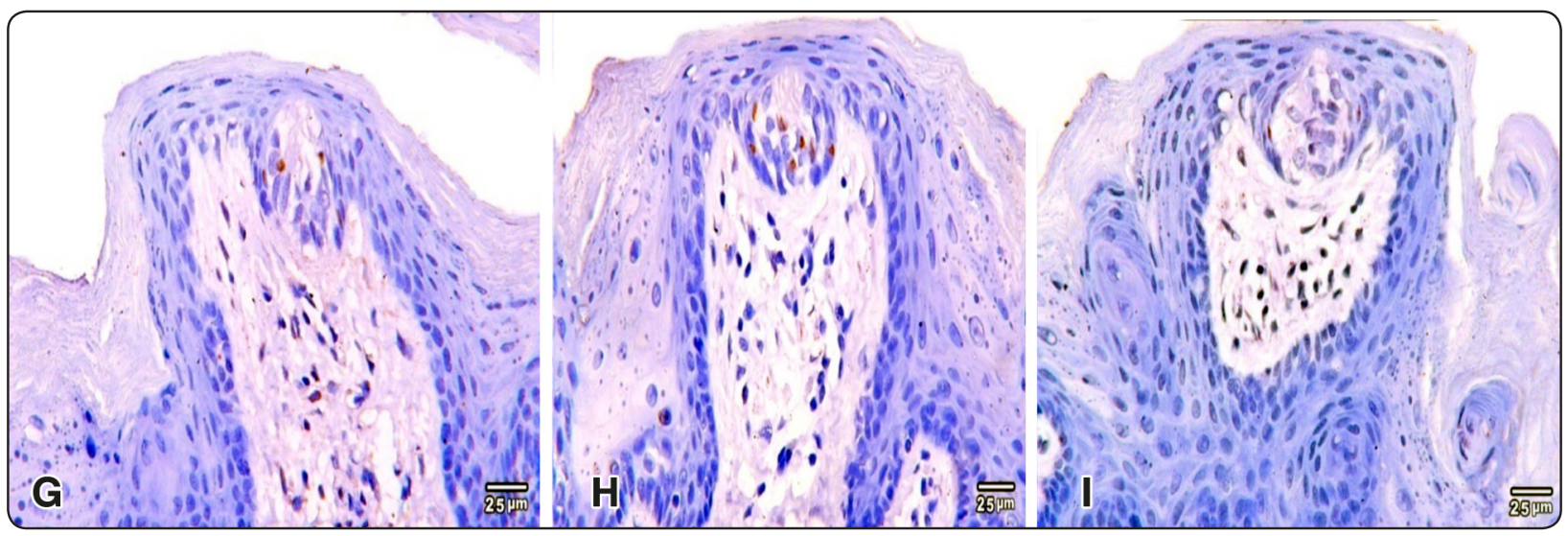

Fig. (3) TNF $\alpha$ immunostain sections G, H and I. (X. 400). Scale bar is 25. 


\section{Statistical results:}

There are significant differences between all groups in the bud/papilla ratio in histological sections and cytokeratin and TNF $\alpha$ expression, (sig: 0.00). Post hoc test revealed the differences between one group and the 2 other in both HE and other immunohistochemical stains.

\begin{tabular}{|c|c|c|c|c|}
\hline \multicolumn{5}{|c|}{ Descriptives } \\
\hline & $\mathrm{HE}$ & $\begin{array}{c}\text { Cytokeratin } \\
7\end{array}$ & TNF & \\
\hline \multirow{4}{*}{ 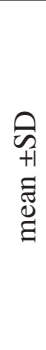 } & $\begin{array}{l}.18367 \pm \\
.009165\end{array}$ & $\begin{array}{c}.3557 \pm \\
.04577\end{array}$ & $\begin{array}{l}.1000 \pm \\
.01826\end{array}$ & Group I \\
\hline & $\begin{array}{c}.09456 \pm \\
.005247\end{array}$ & $\begin{array}{c}.0286 \pm \\
.02116\end{array}$ & $\begin{array}{l}.3371 \pm \\
.06184 \\
\end{array}$ & Group II \\
\hline & $\begin{array}{c}.10656 \pm \\
.002877\end{array}$ & $\begin{array}{c}.1629 \pm \\
01149\end{array}$ & $\begin{array}{l}1644 \pm \\
02419\end{array}$ & Group III \\
\hline & $\begin{array}{c}.12826 \pm \\
.040692\end{array}$ & $\begin{array}{c}03084 \pm \\
.1181\end{array}$ & $\begin{array}{c}.2005 \pm \\
10931\end{array}$ & Total \\
\hline
\end{tabular}

\begin{tabular}{|c|c|c|c|c|}
\hline \multicolumn{5}{|c|}{ One-way Anova } \\
\hline Sig & .000 & & .000 & .000 \\
\hline \multicolumn{5}{|c|}{ Multiple Comparisons LSD } \\
\hline & & \multicolumn{3}{|c|}{ Significance } \\
\hline \multirow{2}{*}{\multicolumn{2}{|c|}{$\begin{array}{l}\text { Group I II } \\
\text { III }\end{array}$}} & 0 & 0 & 0 \\
\hline & & 0 & 0 & .007 \\
\hline \multirow{2}{*}{$\begin{array}{l}\text { Group II } \\
\text { III }\end{array}$} & I & 0 & 0 & 0 \\
\hline & & .0 & 0 & 0 \\
\hline \multirow{2}{*}{$\begin{array}{l}\text { Group III } \\
\text { II }\end{array}$} & & .000 & .000 & .007 \\
\hline & & .000 & .000 & .000 \\
\hline
\end{tabular}

*. The mean difference is significant at the 0.05 level.

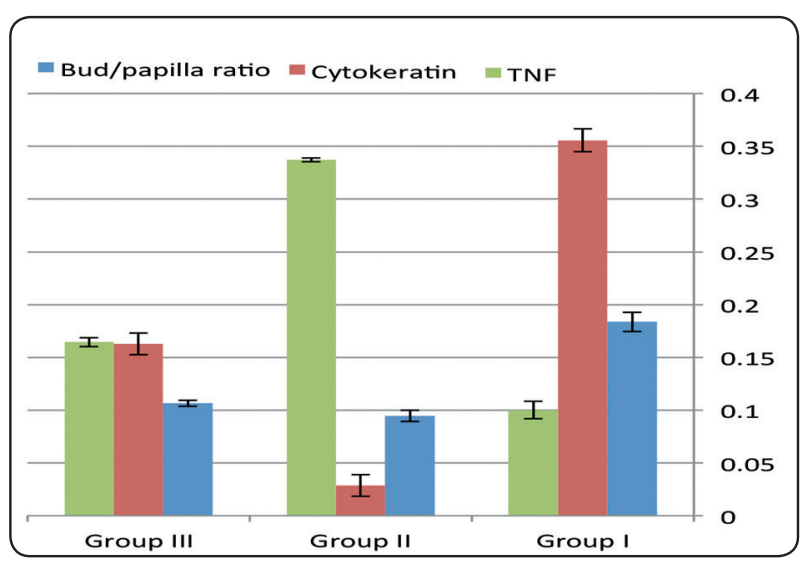

\section{DISCUSSION}

As the toxic chemical compounds present in traditional types of tobacco does not found in E-cig, the inhalation of the constituents of ECs might be considered safer. As a consequence, E-cigarette is a method of harm reducing that can lower the risk of health associated with nicotine use with its combustible tobacco. But electronic cigarettes refill fluids have not experimentally proved to be safe and less risky product. Some researchers reported that E-cig produce toxic carbonyl compounds generated from heat decomposition reactions. These substances can adversely affect the health; but, mostly to a lesser degree than those in tobacco cigarette smoke, ${ }^{(21)}$.

Since the origin of taste bud cells is epithelial, cytokeratins (CKs) could be good index of differentiation of taste buds' cells. Taste buds are the simple columnar epithelium enclosed by stratified squamous epithelium. 5 CKs molecules, cyto7, cyto 8 , cyto18, cyto19, and cyto 20 , all of them can be expressed in simple columnar epithelium. They were documented to be expressed in taste buds cells but not in the surrounding non-taste epithelial cells of the tongue ${ }^{(22,23)}$. CKs are intermediate filament proteins characterize epithelial cells. Cyokeratin 7 is a useful marker in the study of development and expression of taste buds, ${ }^{(22,24)}$. In this study we used cytokeratin 7 antibodies for identification of taste buds in the fungiform papillae According to our knowledge, there are no data available in the literature about the effect of E-cigarette refill liquid on taste buds of fungiform papilla in rats.

The dynamic state of taste buds and tongue papillae makes them an ideal model for searching in taste and neuroplasticity, ${ }^{(14) .}$ The cells of taste buds, revealed to the oral environment face great challenges in defense against pathogenic microorganism. Elevated inflammatory cytokines like tumor necrosis factor- $\alpha$ (TNF- $\alpha$ ) are expressed selectively from specific subset of taste cells, ${ }^{(25)}$. 
TNF- $\alpha$ and its receptors are known to orchestrate different cellular signaling pathways which have effects on cell growth, differentiation, proliferation, and survival, (26). The presence and production of tumor necrosis factor - $\alpha$ in taste tissues were further confirmed immunohistochemically using a specific antibody against Tumor necrosis factor- $\alpha,{ }^{(25)}$.

The absence of cytokeratin immunoreactions in group II indicates an oxidative reaction to the taste cells that induce autophagy. This observation coincides with, Scherz-Shouval 2007, (27) in his study where they proved a role of reactive oxygen species in autophagy but contradict with, Ahruem et al 2017, ${ }^{(28)}$ who found a generation of oxygen radicals in retinal pigment epithelium cell lines exposed to $\mathrm{H} 2 \mathrm{O} 2$ for 12 or 24 hs. They reported, a prolonged exposure to oxidative stress after $24 \mathrm{hs}$ of paraquat (oxidative agent) treatment resulted in aggregation of microtubule-associated protein light chain. Ahruem et al 2017 showed significant increase in KRT8 (keratin 8) which act as a potential marker protein associated with the oxidative stress induced-autophagy. Also, during chronic exposure, the altered CK18 expression could modify differentiation patterns in liver, compromising the cellular physiology by impairing the protective role of CK18 and inducing hepatic susceptibility to further toxic injury, ${ }^{29,30)}$. The gene expression alteration in the keratin-mutant livers led them to hypothesize that altered protein and modifications in the lipid caused by oxidative stress may be generated because of the mutation of keratin, ${ }^{(31)}$. The mechanism through which keratin mutations alter the transcription of a variety of genes that increase susceptibility to oxidative injury may involve modulation of the keratin cytoskeleton interaction with, and regulation of, several signaling cascades, ${ }^{(32,33)}$.

The statistical difference in TNF- $\alpha$ expression agrees with Mahmoud and Amer 2014, ${ }^{(18)}$. They reported that treatment with nicotine $5 \mathrm{mg} / \mathrm{kg}$ i.p daily for 3 weeks caused significant rise in maloendehyde (MDA) levels in both renal and hepatic tissues of rats compared with both saliva and vitamin $\mathrm{C}$ groups. The co-administration of nicotine and vit-C caused significant reduction in MDA level in renal and hepatic tissue compared to nicotine treated group. The bud/papilla ratio reduction in histological sections in group III (0.1 \pm 0.002 ) confirms the antioxidant role of vit $\mathrm{C}$ and sharing in proliferating capacity of taste buds as indicated by increase expression of cytokeratin 7 that support the prophylactic effect of vit C. This observation coincide with the conclusion of Mahmoud and Amer 2014, ${ }^{(18)}$ who reported that, the co-administration of vit- $\mathrm{C}$ with nicotine improve the proliferating capacity of renal and hepatic tissues as indicated by increase in PCNA expression and they noticed that nicotine is shown to have antiproliferative properties.

In periodontics, exposure to e-vapor directly could have deleterious effects on periodontal ligament and gingival fibroblasts in culture caused by the creation of (ROS) reactive oxygen species/ aldehydes/carbonyls from e-cigarette aerosol, leading to protein carbonylation of extracellular matrix and DNA adducts/damage ${ }^{(34)}$.

The significant expression of TNF $\alpha$ in group II agree with Wang et al $2007^{(35)}$, in their research. They tested whether pro-inflammatory agent can stimulate production of tumor necrosis factor $\alpha$ in taste buds in vivo. They injected C57BL16 mic intraperitonealy with lipopolysaccharides $(5 \mathrm{mg} / \mathrm{kg}$ body wt ) a gram -ve bacterial cell wall component that induce systemic inflammatory response. Relative q RT-PCR analysis demonstrated a high level of TNF $\alpha$-mRNA significant in taste epithelium of mice injected with lipopolysaccharides compared with the control animals but did not significantly increase in non taste epithelium. Practically, this means that a diet rich in vitamin $\mathrm{C}$ and quercetin is able to prevent nicotine-induced toxicity and has a beneficial role in the supportive care of people exposed to nicotine, ${ }^{(36)}$. 
According to the results obtained and through their discussions, further investigations in this field are required to better understand the source of carbonyls emitted from E-cig and other effects that may appear.

\section{CONCLUSION}

The use of E-cigarette smoking has a harmful effect on taste buds of fungiform papilla histologically and immunohistochemically. It reduces the relation between surface area of taste bud and their corresponding papilla. In addition, it decreases the expression of cytokeratin 7 and increase the oxidative stress enhancing an increase in TNF $\alpha$ expression that all appeared statistically.

\section{REFERENCES}

1. Pauly JQ, Barry MB. Tobacco-free electronic cigarettes and cigars deliver nicotine and generate concern .Tobacco Control 2007;16(5):357-360.

2. Narges El. Golli, Houssem Dkhili, Yosra Dallagi, Dalila Rahali , Montassar Lasram et al. Comparison between electronic cigarette refill liquid and nicotine on metabolic parameters in rats .Life Sciences 2016;146:131-138.

3. Brandon TH, Goniewicz ML, Hanna NH, Hatsukami DK, Herbst RS, Hobin JA et al. Electronic nicotine delivery systems: a policy statement from the American Association for Cancer Research and the American Society of Clinical Oncology. J Clin Oncol 2015; 33 952-963.

4. Glasser AM, Collins L, Pearson JL, Abudayyeh H, Niaura RS, Abrams DB, Villanti AC. Overview of electronic nicotine delivery systems: a systematic review. Am J Prev Med 2017;52: e33-e66.

5. Walton KM, Abrams DB, Bailey WC, Clark D, Connolly GN, Djordjevic MV, et al . NIH electronic cigarette workshop: developing a research agenda. Nicotine Tob Res 2015; 17: 259-269.

6. Arrazola RA, Singh T, Corey CG, Husten CG, Neff LJ, Apelberg BJ et al. Centers for Disease, C. Prevention, Tobacco use among middle and high school students - United States, 2011-2014. Morb Mortal Wkly Rep 2015;64: 381-385.
7. Herrington JS and Myers C. Electronic cigarette solutions and resultant aerosol profiles. Journal of chromatography A $2015 ; 1418: 192-199$.

8. Cohen A and George O. Animal models of nicotine exposure: relevance to second-hand smoking, electronic cigarette use, and compulsive smoking. Frontiers in psychiatry $2013 ; 4$ p 41.

9. Phillips B, Titz B, Kogel U, Sharma D, Leroy P, Xiang Yet al. Toxicity of the main electronic cigarette components, propylene glycol, glycerin, and nicotine, in Sprague-Dawley rats in a 90-day OECD inhalation study complemented by molecular endpoints. Food and Chemical Toxicology 2017; 109: 315-332.

10. Boulay MÈ, Henry C, Bossé Y, Boulet LP and Morissette MC.Acute effects of nicotine-free and flavour-free electronic cigarette use on lung functions in healthy and asthmatic individuals. Respiratory research 2017; 18(1), p.33.

11. Helen GS, Dempsey DA, Havel CM, Jacob P and Benowitz NL. Impact of e-liquid flavors on nicotine intake and pharmacology of e-cigarettes. Drug \& Alcohol Dependence $2017 ;$ 178:391-398.

12. Drewnowski A. Taste preferences and food intake. Annu Rev Nutr 1997;17:237-53.

13. Chaudhari N and Roper SD. The cell biology of taste. J Cell Biol 2010;190:285-96.

14. Jui-Chin Hsu, IppeiWatari, Rieko Ono, Jutiporn Privatananupunt, Mariko Mizumachi-Kubono, Koji Honda, Yuji Ishida \& Takashi Ono. Degeneration of fungiform and circumvallate papillae following molar extraction in rats. Acta Odontologica Scandinavica 2014; Early Online, 1-7.

15. Ekenedilichukwu OJ, Solomon IC, Chukwuemeka OE, Adamma AR, Athanatius, $\mathrm{OO}$ et al. The effects of cigarette smoking on the serum levels of some antioxidants (vitamin $\mathrm{C}$ and E) amongst male smokers. In Levels In College Of Health Sciences, NnamdiAzikiwe University, Nnewi Campus, Anambra State. International Journal of Scientific Research and Management 2018; 6(01):6-11.

16. J Du JJ Cullena and Buettnera GR . Ascorbic acid: Chemistry, biology and the treatment of cancer. Biochim Biophys Acta 2012;1826:(2): 443-457.

17- Golli NE, Dkhili H, Dallagi Y, Rahali D, Lasram M et al. Comparison between electronic cigarette refill liquid and nicotine on metabolic parameters in rats. Life sciences 2016; 146:131-138. 
18- Mahmoud, G.S. and Amer, A.S., 2014. Protective effects of vitamin $\mathrm{C}$ against nicotine-induced oxidative damage of rat liver and kidney. IOSR-JESTFT, 8(12), pp.50-63.

19- Grawish M, Zyada M, Zaher R. Inhibition of 4-NQOinduced F433 rat tongue carcinogenesis by oleuropein-rich extract. Med Oncol. 2011; 28(4):1163-1168.

20- Mohamad Helal and Mohamed Abdel Rahman .Ki-67 Expression in Major Salivary Glands Exposed to Mobile Cell Phone Radiation . Egyptian Dental Journal 2012; 58(3):2460-2465.

21- Singh CR. and Kathiresan K. Effect of cigarette smoking on human health and promising remedy by mangroves. Asian Pacific Journal of Tropical Biomedicine 2015; 5(2):162-167.

22- Knapp L, Lawton A, Oakley B et al. Keratins as markers of differentiated taste cells of the rat. Differentiation 1995; 58:341-349.

23- Zhang C and Oakley B. The distribution and origin of Keratin 20- containing taste buds in rat and human. Differentiation 1996; 61: 121-127

24- Asano-Miyoshi M, Hamamichi R, Emori Y. Cytokeratin 14 is expressed in immature cells in rat taste buds. J Mol Histol 2008;39:193-199.

25- Pu Feng1, Hang Zhao, Jinghua Chai, Liquan Huang, Hong Wang. Expression and Secretion of TNF-a in Mouse Taste Buds: A Novel Function of a Specific Subset of Type II Taste Cells. Plos One 2012; 7(8): e43140 abstract.

26- Gaur U, Aggarwal BB. Regulation of proliferation, survival and apoptosis by members of the TNF superfamily. BiochemPharmacol 2003; 66: 1403-1408.

27- Scherz-Shouval R, Shvets E, Fass E, Shorer H, Gil L, Elazar Z. Reactive oxygen species are essential for autophagy and specifically regulate the activity of Atg4. EMBO J 2007; 26:1749-1760.
28- Ahruem Baek, Soojin Yoon, Jean Kim, Yu Mi Baek, Hanna Park, Daehan Lim et al. Autophagy and KRT8/keratin 8 protect degeneration of retinal pigment epithelium under oxidative stress. Autophagy 2017;13(2): 248-263

29- Ku NO, Darling JM, Krams SM, Esquivel CO, KeeVe EB, Sibley RK. Keratin 8 and 18 mutations are risk factors for developing liver disease of multiple etiologies. Proc Natl Acad Sci 2003; 100:6063-6068.

30- Omary MB, Coulombe PA, McLean WH. Intermediate filament proteins and their associated diseases. $\mathrm{N}$ Engl $\mathrm{J}$ Med 2004; 351:2087-2100.

31- Qin Zhou, Xuhuai Ji, Lixin Chen, Harry B. Greenberg, Shelly C. Lu, and M. Bishr Omary. Keratin Mutation Primes Mouse Liver to Oxidative Injury Hepatology 2005;41:517-525.

32- Coulombe PA and Omary MB. "Hard" and "soft" principles defining the structure, function and regulation of keratin intermediate filaments. Curr Opin Cell Biol 2002;14:110-122.

33- Paramio JM, Jorncano JL. Beyond structure: do intermediate filaments modulate cell signaling? Bioessays 2002;24:836-844.

34- Javed1 F, Kellesarian SV, Sundar IK, Romanos GE, Rahman I. Recent updates on electronic cigarette aerosol and inhaled nicotine effects on periodontal and pulmonary tissues. Oral Diseases 2017 10.1111/odi.12652.

35- Wang H, Zhou M, Brand J, Huang L. Inflammation activates the interferon signaling pathways in taste bud cells. $\mathrm{J}$ Neurosci 2007; 27: 10703-10713.

36- Milica G. Paunović, Branka I. Ognjanović, Miloš M. Matić, Andraš Š. Štajn, and Zorica S. Saičić. Protective effects of quercetin and vitamin $\mathrm{C}$ against nicotine-induced toxicity in the blood of Wistar rats. Arh Hig Rada Toksikol 2016;67:304-310. 